\title{
Pentingnya Mengetahui Konsep Dasar Proses Keperawatan
}

\author{
Intan Faadhilah
}

Intanfaadhilah24@gmail.com

\section{Latar Belakang}

Proses keperawatan merupakan metode ilmiah yang dipakai dalam memberikan asuhan keperawatan yang profesional. Perawat,dimana saja ia bertugas,menghadapi klien dengan segala macam kasus, dan melayani klien pada semua tingkat usia juga harus menggunakan prosesmkeperawatan.Perawat diharapkan memahami tentang konsep proses keperawatan dan mampu menerapkan serta menyusunannya dalam sebuah dokumen status kesehatan klien. Kualitas pelayanan ditentukan oleh manajemen asuhan keperawatan. Pelaksanakan asuhan keperawatan dengan menggunakan metode proses keperawatan untuk menyelesaikan masalah pasien, antara pasien dan perawat berhubungan secara langsung dalam pengelolaan asuhan keperawatan. Asuhan profesional dituntut untuk dapat melaksanakan proses keperawatan dengan tepat dan benar. Pemahaman mahasiswa terhadap proses perawatan sangat penting, karena topik ini akan menjadi bagian yang amat penting dalam pelaksanaan asuhan keperawatan. Perbedaan asuhan yang profesional dengan asuhan tradisional terletak pada penggunaan proses keperawatan. Kemampuan perawat dalam menerapkan proses keperawatan dalam asuhannya sudah tidak dapat ditawar lagi apabila meyakini bahwa asuhannya adalah asuhan yang profesional. Oleh karena itu diperlukan suatu metode yang dapat membantu meminimalkan hambatan yang ada dan dapat mencapai tujuan belajar secara optimal dengan pendekatan proses keperawatan. Pada saat ini perawat dihadapkan dengan harapan dengan tuntutan asuhan keperawatan yang berkualitas dan professional sebagai penyedia keperawatan kesehatan terdidik degan baik. Dalam menghadapi tuntutan tersebut, perawat harus memiliki alat yang disebut dengan proses keprawatan. Proses keperawatan merupakan proses yang sistematis yang dilakukan oleh perawat dengan klien/ pasien dalam menentukan asuhan keperawatan ynagdibutuhkan dengan melkaukan pengkajan, penentuan diagnosis, merencanakan tindakan yang akan dilakukan, melakukan tindakan serta mengevaluasi hasil dari tindakan yang telah 
dilakukan dengan berfokus pada klien/ pasien dan berorientasi pada tujuan tiap tindakan asuhan keperawatan. Pelaksanaan proses keperawatan merupakan alat perawat dalam melaksanakan tugas, wewenang dan tanggung jawab yang diembannya. Sebagai seorang perawat proses keperawatan dapat digunakan sebgai pedoman dalam pemecahan masalah, dpaat menunjukkan profesi yang memiliki profesinal ita yang tinggi, serta dapat memberikan kebebasan kepada klien untuk mendapatkan pelayanan yang cukup sesuai dngan kebutuhannya, sehingga dapat dirasakn manfaatnya baik perawat maupun klien.

\section{METODE}

Menggunakan metode literature review.Terhadap beberapa kajian yang berkenaan terhadap judul yang saya ambil. Dengan menggunakan buku referensi,jurnal.Metode pengorganisasian yang sistematis dalam melakukan asuhan keperawatan pada individu,kelompok,dan masyarakat yang berfokus pada identifikasi dan pemecahan masalah dari respons pasien terhadap penyakitnya. Dengan menggunakan metode ini perawat dapat mendemontrasikan tanggung gugat dan tanggung jawab pada klien,sehingga kualitas praktik keperawatan dapat meningkat.Proses keperawatan memberikan kerangka yang dibutuhkan dalam asuhan keperawatan kepada klien,keluarga serta komunitas dan merupakan metode yang efisiensi dalam membuat keputusan klinik serta pemecahan masalah baik aktual maupun potensial dalam mempertahankan kesehatan.

\section{HASIL}

Ilmu Keperawatan didasarkan pada suatu teori yang sangat luas. Proses keperawatan adalah metode di mana suatu konsep diterapkan dalam praktik keperawatan. Hal ini dapat disebut sebagai suatu untuk memecahkan masalah (problem-soluing) yang memerlukan ilmu keterampilan interpersonel yang bertujuan untuk memenuhi kebutuhan klien, keluarga, dan yarakat. Proses keperawatan terdiri atas lima tahap yang berurutan dan saling berhubungan yaitu pengkajian, diagnosis,rencanaan, implementasi, dan evaluasi.Tahap tersebut berintegrasi terhadap fungsi intelektual problem-soluing dalam mendefinisikan suatu asuhan keperawatan. Proses keperawatan merupakan lima tahap yang konsisten sesuai dengan perkembangan keperawatan. Tahap tersebut pertama kali dijabarkan oleh Hall (1955). Pada tahun 1967,Yura dan WaIsh menjabarkan menjadi empat tahap, yaitu pengkajian, perencanaan, implementasi dan evaluasi. Pada tahun yang sama, edisi pertama proses keperawatan dipublikasikan dalam empat 
tahasp pengkajian, perencanaan, implementasi, dan evaluasi. Kemudian pada edisi kedua proses keperawatan yang semakin meningkat dipublikasikan. Pada pertengahan tahun 1970-an,Bloch (1974), Roy (1975), Mundinger dan Jauron (1975), serta Aspinall (1976) menambahkan tahap diagnosis pada proses keperawatan sehingga menjadi lima tahap, yaitu pengkajian, diagnosis,perencanaan, implementasi, dan evaluasi. Saat ini, hampir semua buku keperawatan selalu mencantumkan lima tahap proses keperawatan tersebut dan digunakan sebagai kerangka kerja, dasar,dan pengantar dari kajian ilmu keperawatan. Dengan berkembangnya waktu, proses keperawatan telah dianggap sebagai suatu dasar hukum dalam praktik keperawatan. Pada tahun 1973, American Nursing Association (ANA) menggunakan proses keperawatan sebagai pedoman dalam pengembangan standar praktik keperawatan dan digunakan sebagai suatu kerangka konsep kurikulum Di Indonesia, definisi dan tahap-tahap proses pendidikan keperawatan. keperawatan telah digunakan sebagai dasar gembangan definisi dan standar legal praktik keperawatan dan juga sebagai kriteria dan sertifikasi. Kurikulum pendidikan keperawatan pada setiap jenjang pendidikan (D3, S1, S2, maupun keperawatan sebagai kerangka kerjanya. S3) saat ini telah menggunakan proses keperawatan sebagai kerangka kerjanya.

\section{PEMBAHASAN}

Sejarah Proses Keperawatan

Proses keperawatan merupakan lima tahap yang konsisten sesuai dengan perkembangan profesi keperawatan. Tahap tersebut pertama kali dijabarkan oleh Hall (1995). Pada tahun 1967, Yura dan Walsh menjabarkan menjadi empat tahap, yaitu pengkajian, perencanaan, implementasi, dan evaluasi. Pada tahun yang sama, edisi pertama proses keperawatan dipubikasikan dalam empat tahap yang meliputi pengkakjian, perencanaan, implementasi, dan evaluasi. Kemudian pada edisi kedua (1973), proses keperawatan semakin meningkat dipublikasikan. Pada pertengahan tahun 1970-an, Bloch (1974), Roy (1975), Mundunger dan Jauron (1975) serta Aspinal (1976) menambahkan tahap diagnosis pada proses keperawatan sehingga menjadi lima tahap yaitu pengkajian, diagnosis, perencanaan, implementasi, dan evaluasi. Dengan berkembangnya waktu, proses keperawatan telah dianggap sebagai suatu dasar hukum dalam praktik keperawatan. Pada tahun 1973, American Nursing association (ANA) menggunakan proses keperawatan sebagai pedoman dalam pengembangan standar praktik keperawatan dan digunakan sebagai suatu kerangka konsep kurikulum pendidikan keperawatan. Di Indonesia, definisi dan tahap-tahap 
proses keperawatan telah digunakan sebagagai dasar pengembangan definisi dan standar legal praktik keperawatan dan juga sebagai kriteria dalam program sertifikasi. Kurikulum pendidikan keperawatan pada setiap jenjang pendidikan (D3, S1, S2, maupun S3) saat ini telah menggunakan proses keperawatan sebagai kerangka kerjanya (Nursalam, 2008). Proses keperawatan adalah serangkaian tindakan yang sistematis berkesinambungan meliputi tindakan untuk mengidentifikasi masalah kesehatan individu atau kelompok baik yang aktual maupun potensial kemudian merencanakan tindakan untuk menyelesaikan,mengurangi,atau mencegah terjadinya masalah baru dan melaksanakan tindakan atau menugaskan orang lain untuk melaksanakan tindakan keperawatan serta mengevaluasi keberhasilan dari tindakan yang dikerjakan.Asuhan keperawatan adalah kerangka kerja dan struktur organisasi yang Proses keperawatan adalah serangkaian tindakan yang sistematis berkesinambungan meliputi tindakan untuk mengidentifikasi masalah kesehatan individu atau kelompok baik yang aktual maupun potensial kemudian merencanakan tindakan untuk menyelesaikan,mengurangi,atau mencegah terjadinya masalah baru dan melaksanakan tindakan atau menugaskan orang lain untuk melaksanakan tindakan keperawatan serta mengevaluasi keberhasilan dari tindakan yang dikerjakan. Asuhan keperawatan adalah kerangka kerja dan struktur organisasi yang kreatif untuk memberikan pelayanan keperawatan, namun asuhan keperawatan juga cukup fleksibel untuk digunakan disemua lingkup keperawatan. Dalam mencapai kuaitas asuhan keperawatan yang baik, perawat harus mampu melakukan proses keperawatan yang baik dan benar. Dimana proses keperawatan merupakan sumbangan yang diberikan perawat melalui pelaksanaan proses keperawatan. Proses keperawatan merupakan kerangka pikir yang digunakan oleh seorang perawat untuk melaksanakan fungsi dan tanggung jawabnya secara mandiri. Dalam melakukan proses keperawatan, tahap pertama yakni melakukan (Hidayat, 2002). Fase dari pengkajian meliputi: pengumpulan data, analisis/ validasi data, pengelompokan data dan dokumentasi data. Dalam proses keperawatan ada lima tahap, di mana tahap-tahap tersebut tidak dapat dipisahkan, dan saling berhubungan.Tahap-tahap ini bersama-sama membentuk lingkaran pemikiran dan tindakan yang kontinu, yang mengulangi kembali kontak dengan pasien.Tahap-tahap dalam proses keperawatan tersebut adalah sebagai berikut:

\section{Pengkajian.}

2.Diagnosa keperawatan. 


\section{Perencanaan.}

\section{Pelaksanaan.}

\section{Evaluasi.}

Kelima langkah tersebut dapat dijadikan pedoman dalam mencapai tujuan keperawatan yaitu: meningkatkan,mempertahankan kesehatan atau membuat pasien mencapai kematian dengan tenang pada pasien terminal,serta memungkinkan pasien atau keluarga dapat mengatur kesehatannya sendiri menjadi lebih baik.Lalu tahap pengkajian dari proses keperawatan merupakan proses dinan terorganisasi yang meliputi tiga aktivitas dasar yaitu: Pertama, mengumpulkan data secara sistematis; kedua, memilah dan mengatur data yang dikumpulkan dan ketiga,mendokumentasikan data dalam format yang dapat dibuka kembali. Pengumpulan dan pengorganisasian data harus menggambarkan dua hal yaitu: Status kesehatan pasien. Kekuatan pasien dan masalah kesehatan yang dialami (aktual atau risiko/potensial).Dalam melakukan pengkajian diperlukan keahlian-keahlian (skill) seperti wawancara,pemeriksaan fisik, dan observasi. Hasil pengumpulan data kemudian diklasifikasikan dalam data subjektif dan objektif. Data Subjektif merupakan ungkapan atau persepsi yang dikemukakan oleh pasien. Data Objektif merupakan data yang didapat dari hasil observasi,pengukuran,dan pemeriksaan fisik. Ada beberapa cara pengelompokan data, yaitu:

1. Berdasarkan sistem tubuh.

2. Berdasarkan kebutuhan dasar (Maslow).

3. Berdasarkan teori keperawatan.

4. Berdasarkan pola kesehatan fungsional.

Pengelompokan data berdasarkan teori keperawatan sangat membun dalam proses identifkasi diagnosa keperawatan. Sedangkan pengelompo data berdasarkan sistem tubuh juga sangat berguna dalam memberikan masukan kepada dokter.Lalu Proses keperawatan adalah sarana atau alat yang digunakan oleh seorang perawat dalam bekerja dan tata cara pelaksanaanya tidak boleh dipisahpisah antara tahap pertama, kedua, ketiga dan seterusnya. Tahap pertama pengkajian, tahap kedua menegakkan diagnosa 
keperawatan, tahap ketiga menyusun rencana keperawatan yang mengarah kepada penanganan diagnosa keperawatan, tahap keempat diimplementasikan dan tahap kelima atau tahap terakhir adalah evaluasi. Orientasi dari pelayanan asuhan keperawatan adalah pada pencapaian tujuan asuhan keperawatan. Asuhan keperawatan yang telah ditetapkan dalam perencanaan keperawatan telah tercapai (Budiono, 2016). Proses keperawatan dimulai segera setelah Anda memasuki perawat-klien. Pengkajian keperawatan adalah berkelanjutan mengenai pengumpulan data dan analisis informasi secara sistematis dan klien.Pengkajian imulai dengan mengumpulkan data dan menempatkan data kedalam format yang terorganisir.Prioritas data sangat penting.Selama fase pengkajian mengumpulkan data perawat mulai menerima dan mengidentifikasi masalah atau kebutuhan yang ada. Kebutuhan yang ada sering menjadi prioritas di atas kebutuhan potensial,yang sering ditulis sebagai risiko. Misalnya, tujuan dan kebutuhan klien untuk ditulis pulih dari cedera serebrovaskular (stroke) memiliki prioritas hubungan lebih tinggi dari kebutuhan potensial seperti resiko infeksi. Sumber informasi terbaik mengenai klien adalah klien dan keluarga. Anda juga berkonsultasi dengan anggota tim layanan kesehatan lain untuk mendapat informasi dan analisis dari mereka mengenai klien. Selain itu, Anda mempelajari informasi dari catatan kesehatan klien sebelumnya dan saat ini, laporan laboratorium, dan buku referensi yang berkaitan dengan diagnosis medis atau kondisi klien. Pemeriksaan fisik juga memberikan data penting.

\section{PENUTUP}

Dari kajian ini dapat di simpulkan bahwa, pentingnya mengetahui konsep dasar dalam keperawatan sangat penting dalam menjalankan asuhan keperawatan. Sehingga perlu diketahui, bagaimana pentingnya mengetahui konsep dasar, dalam melakukan tindakan. Oleh karena itu, sangat penting untuk perawat dalam menghadapi berbagai situasi. Dan proses keperawatan merupakan metode dalam memecahkan masalah keperawatan yang bersifat terbuka dan fleksibel dalam memenuhi kebutuhan pasien dengan memberikan asuhan keperawatan dengan dilakukan secara sistematis sehingga meningkatkan kualitas pelayanan keperawatan.

\section{REFERENSI}

Alimul, A. A. (2006). Pengantar Kebutuhan Dasar Manusia Aplikasi Konsep dan Proses Keperawatan. Jakarta: Salemba Medika. 
Allen, C. V. (1998). Memahami Proses Keperawatan dengan Pendekatan Latihan. Jakarta: EGC. Simamora,R.H. (2019). Menjadi Perawat yang : CIH'HUY. Surakarta : Kekata Publisher.

Siswanto, L, Hariyati, Rr, Sukihananto, 2013. Faktor-Faktor Yang Berhubungan Dengan Kelengkapan Pendokumentasian Asuhan Keperawatan, Jurnal Keperawatan Indonesia. 1(2) :77-84.

Kodim, Yulianingsih. (2015). Konsep Dasar Keperawatan. jakarta: TIM.

Nursalam. (2008). Proses dan Dokumentasi Keperawatan. Jakarta: Salemba Medika.

Potter, P. A., \& Perry, A. G. (2005). Buku Ajar Fundamental Keperawatan : Konsep, Proses, dan Praktik (edisi 4). JakAarta EGC

Bumulo, M. I., Bidjuni, H., \& Bawotong, J. (2017, Agustus). Pengaruh Manajemen Model Asuhan Keperawatan Profesional Tim terhadap Kualitas Pelayanan Keperawatan di

Bangsal Pria RSUD Datoe Binangkang Kabupaten Bolang Mongondow. e-Jurnal Keperawatan (e-Kp),5,1-6.

Husna, A. (2019). Tingkat Berpikir Kritis Dalam Keperawatan. Osf.io

Kartika, I. R., Hariyati, R. S., \& Nelwati. (2018, Maret). Kompetensi Perawat dan Kepuasan Pasien Terhadap Pelayanan Keperawatan di Rawat Jalan Volume 14 No. 2. Jurnal Kepera Khamida, \& Mastiah.(2015,Agustus 